\title{
Computed tomography - and magnetic resonance imaging-based Bosniak Classification of Cystic Renal Masses Version 2019: a comprehensive review and comparison to version 2005
}

\section{Klasyfikacja zmian torbielowatych nerek według Bosniaka w tomografii komputerowej i rezonansie magnetycznym, wersja z 2019 roku- przegląd piśmiennictwa i porównanie z wersją z 2005 roku} \author{
Rafał Szpak $^{5}$, Andrzej Cieszanowski ${ }^{6}$

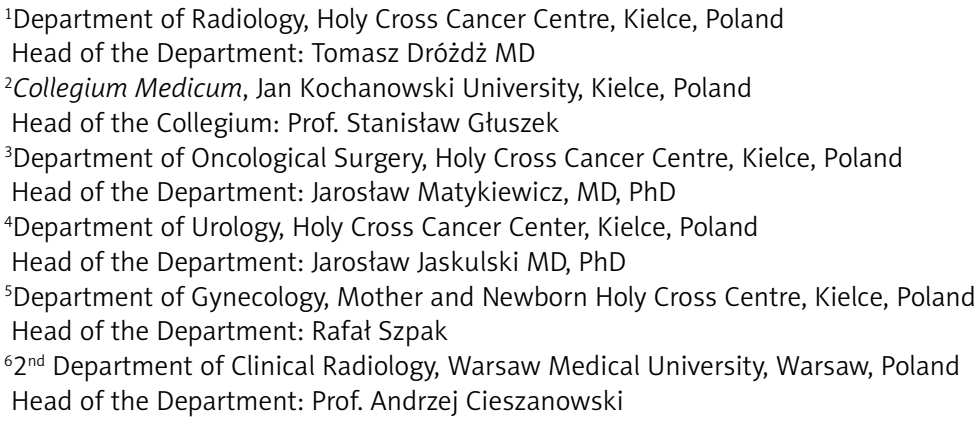

Tomasz Dróżdż ${ }^{1,2}$, Katarzyna Zielińska1,2, Stanisław Głuszek ${ }^{2,3}$, Dawid Dopierała ${ }^{1}$, Marcin Kosowski²,4

Key words: renal cystic masses, Bosniak classification version 2005, Bosniak classification version 2019, interobserver agreement.

Słowa kluczowe: zmiany torbielowate w nerkach, klasyfikacja wg Bosniaka wersja 2005, klasyfikacja wg Bosniaka wersja 2019, zgodność między obserwatorami.

\begin{abstract}
Cystic renal lesions are common findings on abdominal imaging studies. Bosniak Classification version 2005 and 2019 consists of five categories of cystic masses. The 2019 modification is more detailed and extensive compared to version 2005 . The novelties in version 2019 are implementation of diameter values of cystic septa and walls as well as inclusion of magnetic resonance imaging for classification of cystic renal masses. The aim of our study was to review a new proposal for the assessment of renal cysts and review the results of studies which compared diagnostic performance and interobserver agreement of both versions from 2005 and 2019.
\end{abstract}

\begin{abstract}
Streszczenie
Zmiany torbielowate w nerkach występują często w badaniach obrazowych. Klasyfikacja wg Bosniaka, wersja z 2005 roku i 2019 roku, składa się z pięciu kategorii torbielowatych zmian w nerkach. Modyfikacja klasyfikacji z 2019 roku jest bardziej szczegółowa i dokładniejsza w porównaniu z wersją z 2005 roku. Nowością w wersji z 2019 roku jest ocena grubości przegród i ścian w zmianach, jak również uwzględnienie w klasyfikacji obrazów z rezonansu magnetycznego. Celem pracy jest przeanalizowanie nowej propozycji klasyfikacji mas torbielowatych w nerkach oraz przegląd piśmiennictwa, w którym porównywane są dwie klasyfikacje oraz badana jest zgodność pomiędzy obserwatorami przy użyciu dwóch wersji.
\end{abstract}

\section{Introduction}

The Bosniak Classification of cystic renal masses, introduced in 1986 stratified the probability of malignancy on the basis of imaging characteristics in computed tomography (CT) and guided clinical management [1]. The classification system was based on several morphological changes in renal cysts: septa formation, wall thickening, including nodal components, calcification in the wall or septa, hyperdense cystic content and contrast enhancement after intravenous contrast injection. The main objective of this classification was to differentiate nonsurgical (category I/II) from surgical cystic masses (category III/IV). 
Table 1. Details of the current Bosniak classification of cystic renal masses

\begin{tabular}{|ll|}
\hline Class & \multicolumn{1}{c|}{ Current Bosniak Classification } \\
II & Hairline-thin wall; water attenuation; no septa, calcifications, or solid components; non-enhancing \\
& Two types: \\
& 1. Few thin septa with or without perceived (not measurable) enhancement; fine calcification or a short \\
& segment of slightly thickened calcification in the wall or septa \\
2. Homogeneously high-attenuating masses $\leq 3 \mathrm{~cm}$ that are sharply marginated and do not enhance
\end{tabular}

After original description, it became obvious that there were some category II cysts that were slightly more complicated than most category II lesions, but not complicated enough to place them in category III. For that reason, category IIF (F for follow-up) was introduced in 1993. Next refinements were in 2005 and 2019 [2-4]. The most important modifications in version 2019 include the incorporation of magnetic resonance imaging (MRI)-based classification and introduction of detailed measurement of cystic septa and wall thickness, which determines their categorization.

The goals of the update are to reduce interobserver variability and improve ability to predict the likelihood of malignancy in a cystic renal lesion. The most important purpose of the novelties in the classification was to objectify and unify the radiologist's estimate.

The aims of our paper were, first, to discuss and compare the principles of Bosniak classification version 2005 to version 2019 and, second, to summarize the results of published articles investigating diagnostic performance and interobserver agreement of a newly proposed version.

\section{General principles of Bosniak classification (version 2005 vs. version 2019)}

Bosniak Classification 2005 evaluates cystic renal lesions in CT and has five categories: I (benign cysts), II (minimally complicated cysts: benign), IIF (requires CT follow-up), III (more complicated cysts; requires surgery, biopsy controversial), IV (malignant lesions, requires surgery) (Table 1$)$.

Categories I and IV lesions are generally simple for interobservers, but categories II, IIF and III are often more problematic and the studies demonstrated high disagreement between readers [5]. Accurate distinction between categories II, IIF and III is very important and crucial for further treatment as type II cyst does not need any follow-up, type IIF requires followup and type III cystic mass is treated surgically.
Several studies have highlighted limitations of using this classification, including considerable interobserver variability among readers and a significant proportion of benign lesions among Bosniak type III masses [6, 7].

Therefore, there was a demand among radiologists and urologists for improvement of the Bosniak Classification 2005.

The newly proposed Bosniak Classification 2019 defines a cystic mass as a lesion with less than $25 \%$ enhancing components. Similarly to the previous version it also have five categories, but, additionally includes MRI for the assessment of renal cysts. Moreover, the new classification is more precise in the evaluation of walls and septa, due to measurement of their thickness (Figures 1 A-C). Previously used subjective terms, such as "thickened" and "multiple" are now numerically defined and the lesion size have been removed $[4,5]$ (Table 2).

\section{Comparison of Classification 2005 vs Classification 2019 in individual categories (Table 1) [5]}

\section{Bosniak type I masses}

Category I is used to describe simple cysts. In Classification version 2005 there are imprecise terms like "hairline thin wall" which were replaced in the 2019 version by "well-defined, thin $(\leq 2 \mathrm{~mm})$ smooth wall". In the latest edition of the Bosniak classification the wall may enhance, which is a difference in comparison to the previous classification. The criteria in MRI are the same as in CT, however signal intensity of fluid in the cyst is compared to CSF (should have similar signal intensity) (Figure 2).

\section{Bosniak type II masses}

The prevalence of malignancy in cysts categorized as Bosniak II is approximately $0 \%$.

The Bosniak Classification version 2005 defines the following types of lesions in this category: cysts 
A
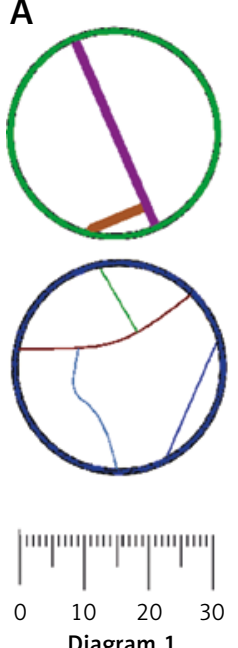

B

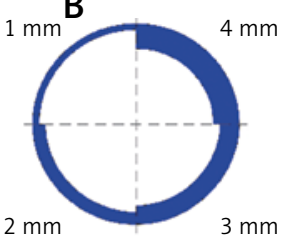

$3 \mathrm{~mm}$
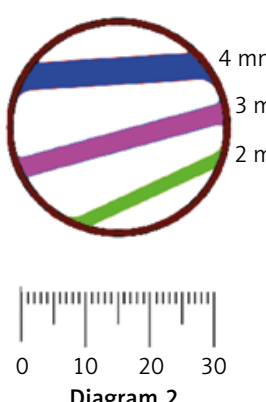

C
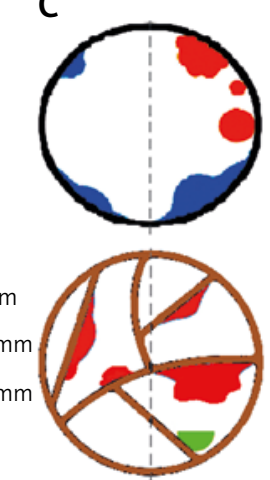

Bosniak III Bosniak IV

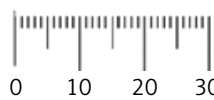

Diagram 3

Figure 1. A - Bosniak II cyst (top) and IIF cystic mass (bottom) classified on the basis of the number of thin ( $\leq 2 \mathrm{~mm}$ ) septa (version 2019). B - Bosniak I cyst: smooth and thin $(\leq 2 \mathrm{~mm})$ wall, Bosniak II cyst: a smooth and thin $(\leq 2 \mathrm{~mm})$ wall and septa, Bosniak IIF cyst: smooth and minimally thickened (3 $\mathrm{mm}$ ) wall or septa, Bosniak III mass: thickened ( $\geq 4 \mathrm{~mm}$ ) enhancing wall or septa (version 2019). C - Bosniak III irregular thickening $(\leq 3 \mathrm{~mm})$, obtuse margins with wall or septa. Bosniak IV: enhancing convex protrusions that arise from a wall or septa are either nodules; any size if they have acute margins with walls or septa or $\geq 4 \mathrm{~mm}$ if they have obtuse margins with the wall or septa (version 2019)

with "few thin septa with or without perceived enhancement; fine calcification or a short segment of slightly thickened calcification in the wall or septa" and "homogenous high-attenuating masses $\leq 3 \mathrm{~cm}$ that are sharply margined and do not enhance". The Bosniak classification 2019 defines that every cyst in this category must have well-defined thin smooth walls with thickness $\leq 2 \mathrm{~mm}$. In the new version, the number of septa is also defined (1-3) (Figure 3). In the new classification, Bosniak type II cyst may have calcifications of any type, whereas in version 2015 cysts with thick or nodular calcifications were defined as IIF (Figures 4 A, B). Both walls and cysts may show contrast enhancement. In version 2019 masses must be homogenous attenuating with precisely described densities at non-contrast CT and at portal venous phase CT. "Homogenous low-attenuating masses that are too small to characterize" are also assigned to Bosniak II category.

The Bosniak Classification, version 2019 includes the following additional entities in MRI: "homogenous masses markedly hyperintense at T2-weighted imaging (similar to CSF) at non-contrast MRI", "homogenous masses markedly hyperintense at T1weighted imaging (approximately $\times 2.5$ normal parenchymal signal intensity) at non-contrast MRI".

\section{Bosniak type II F masses}

The percentage of malignancy in this category is about $5 \%[8]$.

In 2012, Morton Bosniak suggested that Bosniak IIF cysts with minimal findings need follow-up for only 1-2 years, whereas more complex Bosniak IIF cysts should be followed for a longer period (e.g., 3-4 years or longer) [3].

The Bosniak Classification, version 2005 defines lesions in IIF category using ambiguous terms, such as, "minimally thickened", "more than a few thin septa", and "thick and nodular calcification". In version 2019 these terms were changed and clarified by adding measurements of septa and walls: "smooth minimally thickened $(3 \mathrm{~mm})$ enhancing wall of one or more enhancing septa" (Figures 5, 6), "many $(\geq 4)$ smooth thin $(\leq 2 \mathrm{~mm}$ ) enhancing septa" (Figures 7,8 ).

In version 2005 the size criterion of homogenously hyperattenuating and non-enhancing renal masses (with a threshold of $3 \mathrm{~cm}$ ) was important, however this is no longer valid for the new version 2019. The subjective terms such as "perceived" or "measurable" enhancement from the previous classification were abandoned in a new version and replaced by a simple term of "enhancement". Enhancement of the cystic renal mass or its part may be determined if the enhancement is unequivocally perceived by the reader, whereas in masses with equivocal appearance on CT images, contrast enhancement may be better perceived on subtracted MR images.

Some cystic masses in this category may be heterogeneously hyperintense at MR unenhanced fatsaturated T1-weighted imaging, usually indicating previous hemorrhage or high-protein content.

\section{Bosniak type III masses}

Lesions classified to that category have probability to be malignant of about 50\% [9-11].

In 2005 version cysts with thickened irregular or smooth walls or septa with measurable enhancement are classified as type III Bosniak mass. In 2019 version more precise criteria were applied to categorize these lesions: "one or more enhancing thick ( $\geq 4 \mathrm{~mm}$ width) or enhancing irregular (displaying $\leq 3 \mathrm{~mm}$ obtusely margined convex protrusions) walls or septa". They were designed to help radiologists in more accurate and objective classification of cystic lesions detected on CT and MRI.

It is very important to exclude certain lesions from this category, such as, abscesses, post-ablation, posthemorrhagic and posttraumatic cysts. These lesions may undergo careful follow-up instead of surgical excision.

\section{Bosniak type IV masses}

These masses are malignant in approximately 90\% [10]. The Bosniak classification 2005 determines 
Table 2. Proposed update to the Bosniak classificati on of cystic renal masses

\begin{tabular}{|c|c|c|}
\hline Class & CT, version 2019 & MRI, version 2019 \\
\hline | & $\begin{array}{l}\text { Well-defined, thin }(\leq 2 \mathrm{~mm}) \text { smooth wall; homogenous } \\
\text { simple fluid }(-9 \text { to } 20 \mathrm{HU}) \text {; no septa or calcifications; the } \\
\text { wall may enhance }\end{array}$ & $\begin{array}{l}\text { Well-defined, thin ( } \leq 2 \mathrm{~mm} \text { ) smooth wall; } \\
\text { homogenous simple fluid (signal intensity similar to } \\
\text { CSF); no septa or calcifications; the wall may enhance }\end{array}$ \\
\hline II & $\begin{array}{l}\text { Six types, all well-defined with thin }(\leq 2 \mathrm{~mm}) \text { smooth } \\
\text { walls: } \\
\text { 1. Cystic masses with thin }(\leq 2 \mathrm{~mm}) \text { and few }(1-3) \text { septa; } \\
\text { septa and wall may enhance; may have calcification } \\
\text { of any type } \\
\text { 2. Homogeneous hyperattenuating ( } \geq 70 \mathrm{HU}) \text { masses at } \\
\text { noncontrast CT } \\
\text { 3. Homogeneous nonenhancing masses }>20 \mathrm{HU} \text { at renal } \\
\text { mass protocol CT, may have calcification of any type } \\
\text { 4. Homogeneous masses }-9 \text { to } 20 \mathrm{HU} \text { at noncontrast CT } \\
\text { 5. Homogeneous masses } 21 \text { to } 30 \mathrm{HU} \text { at portal venous } \\
\text { phase CT } \\
\text { 6. Homogeneous low-attenuation masses that are too } \\
\text { small to characterize }\end{array}$ & $\begin{array}{l}\text { Three types, all well-defined with thin }(\leq 2 \mathrm{~mm}) \\
\text { smooth walls: } \\
\text { 1. Cystic masses with thin }(\leq 2 \mathrm{~mm}) \text { and few }(1-3) \\
\text { septa; septa and wall may enhance; may have } \\
\text { calcification of any type } \\
\text { 2. Homogenous masses markedly hyperintense } \\
\text { at T2-weighted imaging (similar to CSF) at } \\
\text { noncontrast MRI } \\
\text { 3. Homogenous masses markedly hyperintense at } \\
\text { T1-weighted imaging (approximately } \times 2.5 \text { normal } \\
\text { parenchymal signal intensity) at noncontrast MRI }\end{array}$ \\
\hline II F & $\begin{array}{l}\text { Cystic masses with smooth minimally thickened }(3 \mathrm{~mm}) \\
\text { enhancing wall, or smooth minimal thickening }(3 \mathrm{~mm}) \\
\text { of one or more enhancing septa or many }(\geq 4) \text { smooth } \\
\text { thin }(\leq 2 \mathrm{~mm}) \text { enhancing septa }\end{array}$ & $\begin{array}{l}\text { Two types: } \\
\text { 1. Cystic masses with smooth minimally thickened } \\
(3 \mathrm{~mm}) \text { enhancing wall, or smooth minimal } \\
\text { thickening }(3 \mathrm{~mm}) \text { of one or more enhancing septa } \\
\text { or many }(\geq 4) \mathrm{smooth} \text { thin }(\leq 2) \text { enhancing septa } \\
\text { 2. Cystic masses that are heterogeneously } \\
\text { hyperintense at unenhanced fat-saturated } \\
\text { T1-weighted imaging }\end{array}$ \\
\hline III & $\begin{array}{l}\text { One or more enhancing thick ( } \geq 4 \mathrm{~mm} \text { width) or } \\
\text { enhancing irregular (displaying } \leq 3 \mathrm{~mm} \text { obtusely } \\
\text { margined convex protrusion(s)) walls or septa }\end{array}$ & $\begin{array}{l}\text { One or more enhancing thick ( } \geq 4 \mathrm{~mm} \text { width) or } \\
\text { enhancing irregular (displaying } \leq 3 \mathrm{~mm} \text { ) obtusely } \\
\text { margined convex protrusion(s) walls or septa }\end{array}$ \\
\hline IV & $\begin{array}{l}\text { One or more enhancing nodule(s) ( } \geq 4 \mathrm{~mm} \text { convex } \\
\text { protrusion with obtuse margins, or a convex protrusion } \\
\text { of any size that has acute margins) }\end{array}$ & $\begin{array}{l}\text { One or more enhancing nodule(s) ( } \geq 4 \mathrm{~mm} \text { convex } \\
\text { protrusion with obtuse margins, or a convex } \\
\text { protrusion of any size that has acute margins) }\end{array}$ \\
\hline
\end{tabular}

these lesions as having "soft-tissue components, nodules with measurable enhancement". In version 2019 these lesions are defined more specifically in both CT and MRI as cystic masses with "one or more enhancing nodule(s) ( $\geq 4 \mathrm{~mm}$ convex protrusion with obtuse margins, or a convex protrusion of any size that has acute margins)" [11] (Figure 9).

The differences between both versions are summarized in Table 3.

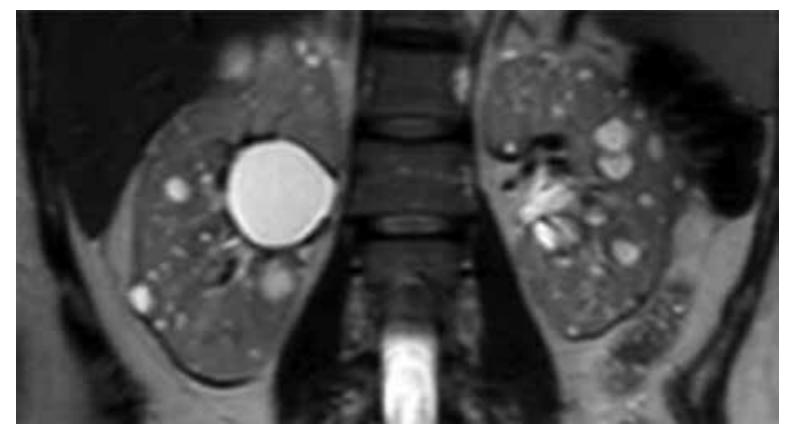

Figure 2. T2-weighted MRI, cystic masses with a thin wall, without septa; Bosniak category I with both original and version 2019 systems

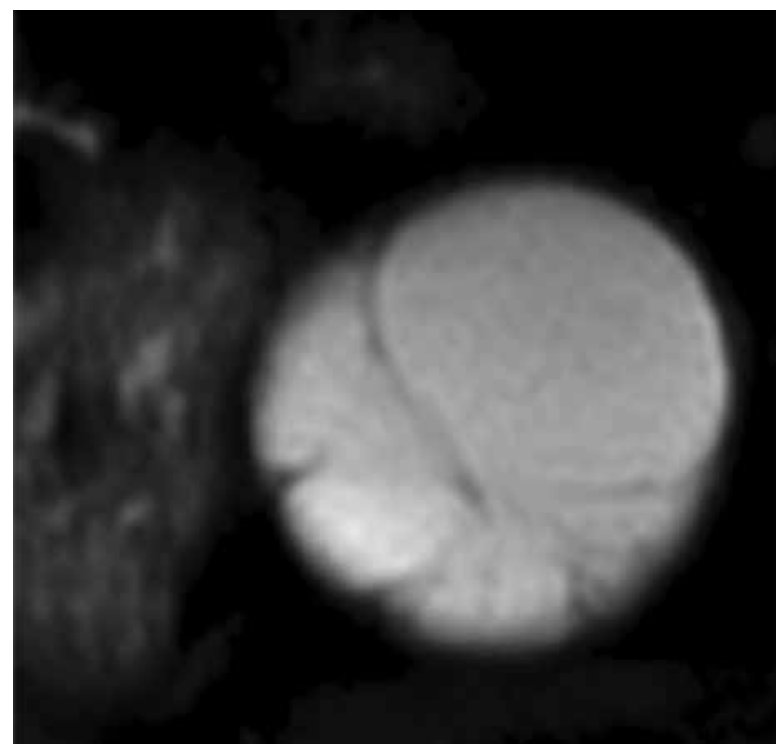

Figure 3. Fat-saturated T2-weighted MR; cystic mass with thin $(\leq 2 \mathrm{~mm})$ septa. Bosniak 2015 category II because of few and thin septa. Version 2019 defines many septa to be four or more, the lesion was upgraded to Bosniak category IIF 

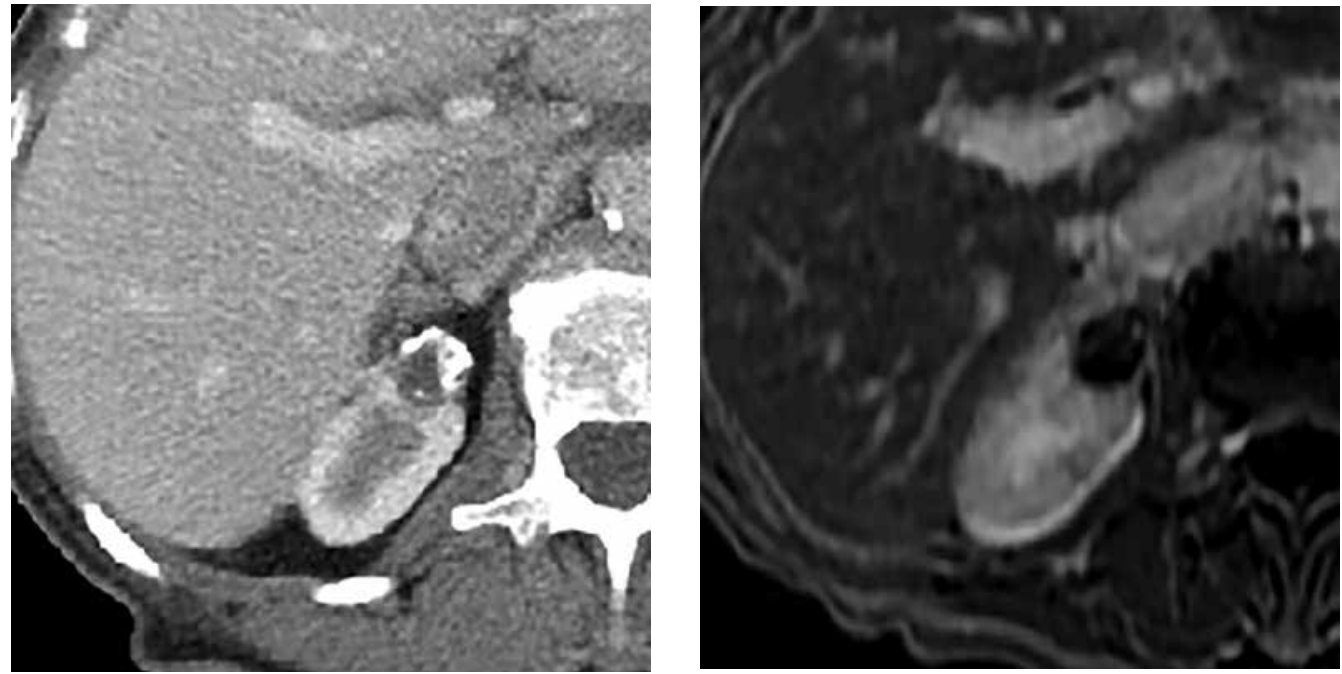

Figure 4. A - Nephrogenic phase CT; nonenhancing mass in thick calcification (B) subtraction T1-image MRI shows few $\leq 3$, thin $\leq 2 \mathrm{~mm}$ enhancing septa; Bosniak IIF in 2005 classification (because of calcification), Bosniak II in the update classification 2019

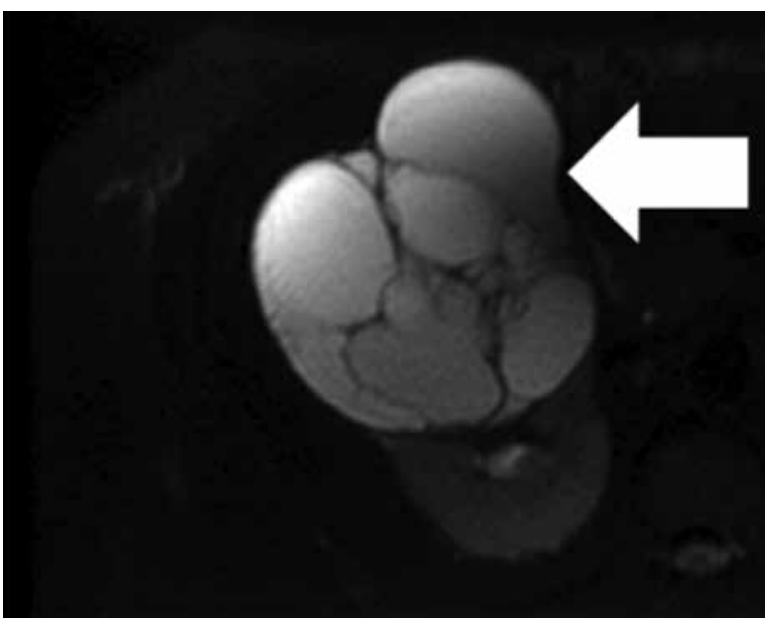

Figure 5. Fat-saturated T2-weighted MR; cystic mass (arrow) was originally classified Bosniak category III on the basis of thickened septa with measurable enhancement. Version 2019 defines thickening of $3 \mathrm{~mm}$, the lesion was downgraded to Bosniak category IIF

\section{Discussion}

Accurate categorization of renal cysts using the Bosniak classification can be challenging due to its subjective criteria and variations in observer's experience and perception. To date several studies evaluating the interobserver agreement and diagnostic performance using versions 2005 and 2019, have been published.

Bai et al. [12] published a study comparing MRIbased Bosniak classification of cyst renal masses from 2019 to its previous version 2005. In the study, eight readers participated and evaluated 207 cystic renal masses. The interobserver agreement among the read-

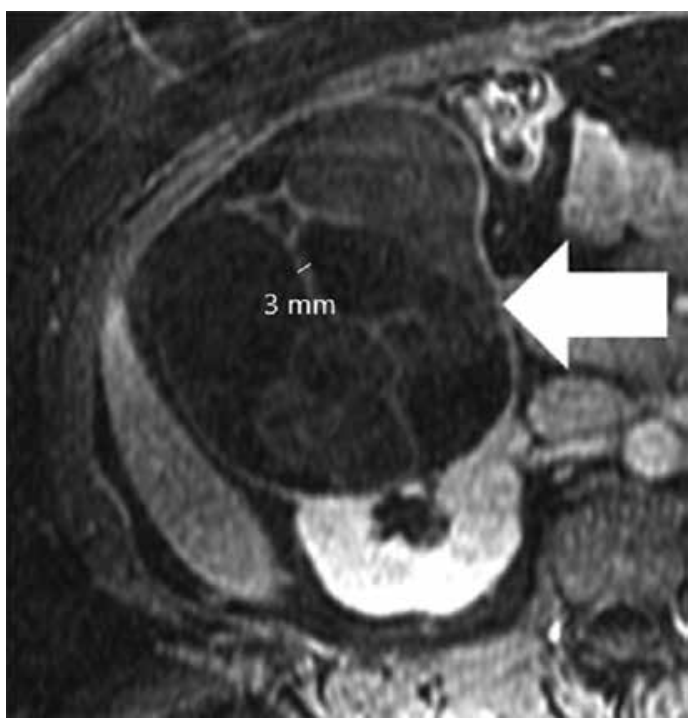

Figure 6. Contrast-enhanced fat-saturated T1-weighted MR image; cystic mass (arrow) was originally classified Bosniak category III on the basis of many and thickened septa. Version 2019 defines thickening as at least $3 \mathrm{~mm}$, the lesion was downgraded to Bosniak category IIF

ers was substantial with version 2019 and only moderate with version 2005 . The interobserver agreement with version 2019 was significantly higher than that of version 2005.

In the study published by Chan et al. [13], three radiologists independently evaluated 65 cystic masses in CT, followed by MRI and assigned Bosniak version 2005 and 2019 in two sessions separated by $\geq 1$ month. The result indicated similar to slightly higher agreement between radiologists when they used Bosniak version 2019. 


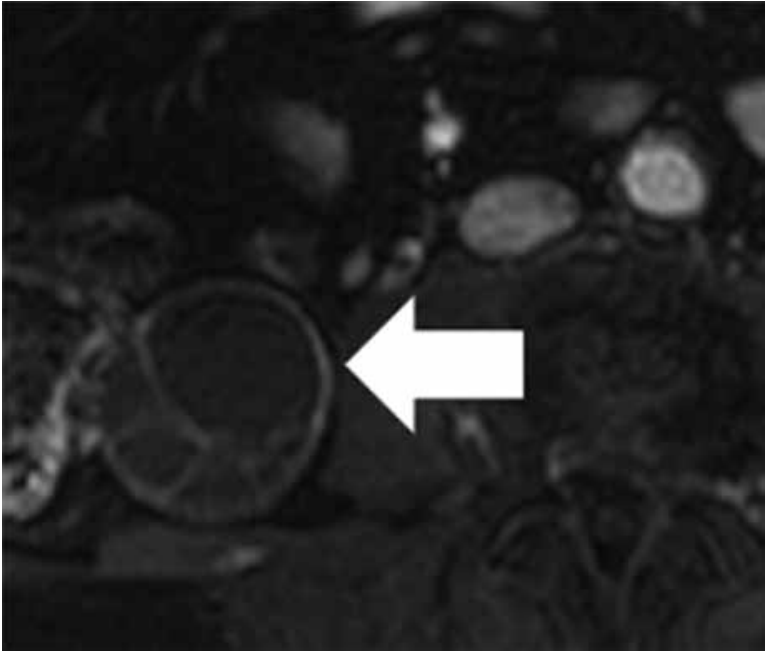

Figure 7. Fat-saturated T1 weighted MRI; cystic mass was originally classified Bosniak category II on the basis of few and thin septa. Version 2019 defines many septa to be four or more, the lesion was upgraded to Bosniak category IIF

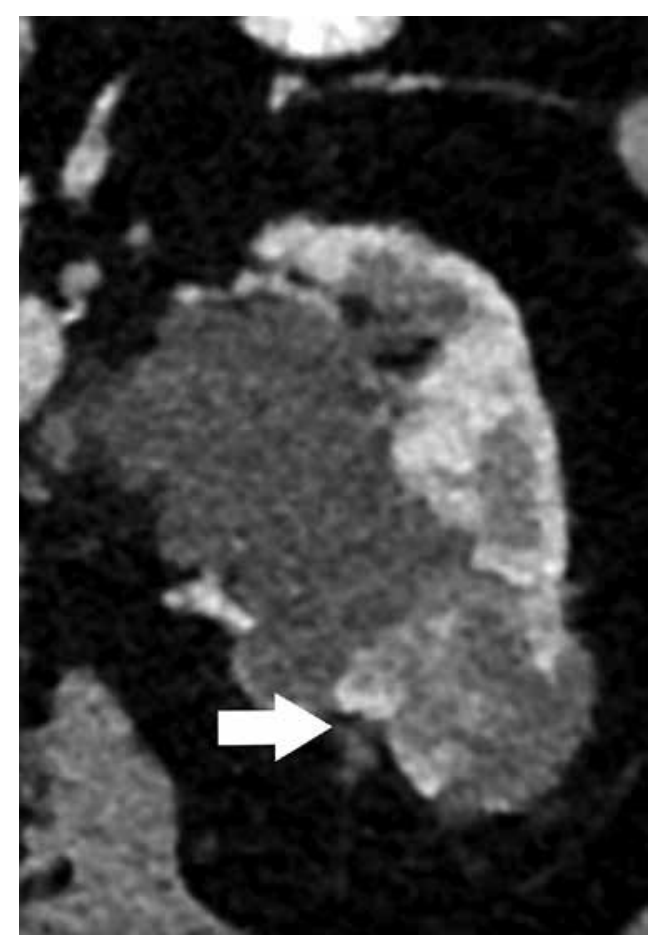

Figure 9. Nephrogenic phase CT; cystic mass with enhancing nodules; Bosniak category IV with both original and version 2019 systems

Tse et al. [14] conducted studies with three abdominal radiologists. The observers retrospectively reviewed 68 consecutive cystic renal masses. Overall interobserver agreement was substantial for both CT and MRI using version 2019 and was slightly higher than that of the original system for CT.

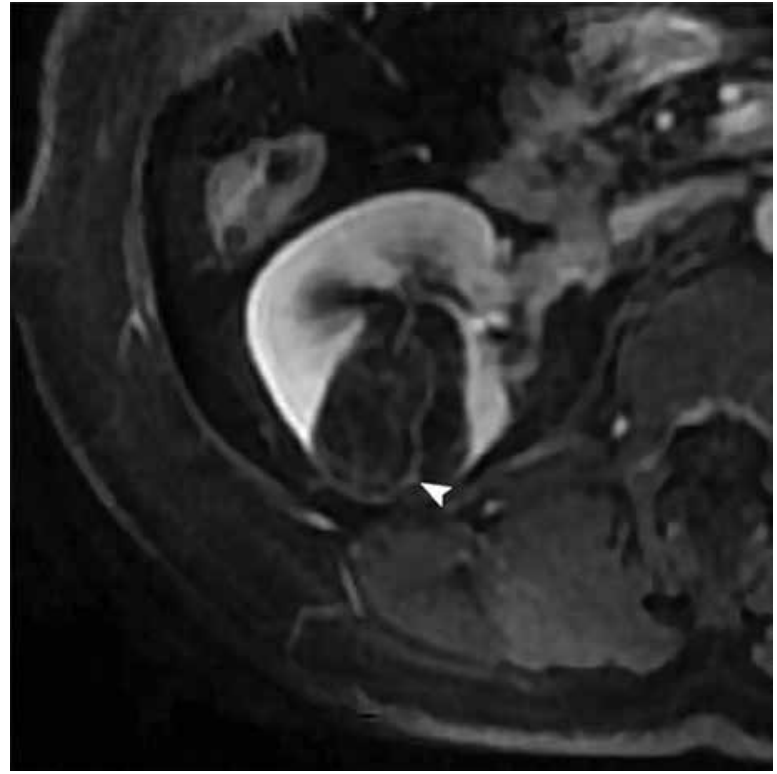

Figure 8. T1-weighted MRI scan; class IIF according to Bosniak 2005 because of more than a few septa and class IIF according to Bosniak 2019 because of the irregular enhancing septa also as class IIF

Yan et al. [15] selected 73 cystic masses and three radiologists evaluated them. Interobserver agreement was slightly improved comparing version 2019 to the original Bosniak classification. Authors concluded that the Bosniak classification version 2019 may categorize a higher proportion of malignant masses in class IIF.

In another study, which was also performed by Tse et al. [16], two abdominal radiologists analyzed 50 cystic renal mass in MR images. The results demonstrated moderate agreement for both the original system and version 2019 .

The study conducted by Park et al. [17] analyzed agreement using CT and MRI. The assessment was done by two radiologists who categorized 104 cystic renal masses according to both versions of Bosniak classification from 2005 and 2019. The result indicated that interobserver agreement is similar between versions.

The results of a study published by Pacheco et al. [18] were based on the evaluation done by eighteen non-subspecialized readers who categorized 50 renal cystic masses in CT and MRI. The assessment with Bosniak classification version 2019, compared to version 2005, did not improve interobserver agreement.

\section{Conclusions}

Observation and treatment of patients with cystic renal masses depend on the correct categorization of renal cysts according to the most commonly used Bosniak classification. Modifications of the classification in 1993 and 2005 led to improvement in the quality of radiologist's assessment and agreement between 
Table 3. The differences between both versions

\begin{tabular}{|c|c|c|}
\hline Class & Version 2005 (CT) & Version 2019 (CT, MRI) \\
\hline I & $\begin{array}{l}\text { - Hairline-thin wall } \\
\text { - Water attenuation } \\
\text { - Nonenhancing wall }\end{array}$ & $\begin{array}{l}\text { - Well-defined, thin }(\leq 2 \mathrm{~mm} \text { ) smooth wall } \\
\text { - CT: } \\
\text { - Homogenous simple fluid (-9 to } 20 \mathrm{HU}) \\
\text { - MR: } \\
\text { - Homogenous simple fluid (signal intensity similar } \\
\text { to CSF) } \\
\text { - The wall may enhance }\end{array}$ \\
\hline II & $\begin{array}{l}\text { - Few thin septa } \\
\text { - Septa without perceived (not measurable) } \\
\text { enhancement } \\
\text { - Fine calcification or a short segment of slightly } \\
\text { thickened calcification in the wall or septa } \\
\text { - High-attenuating masses } \leq 3 \mathrm{~cm} \text { and do not } \\
\text { enhance }\end{array}$ & $\begin{array}{l}\text { - Thin ( } \leq 2 \mathrm{~mm} \text { ) and few }(1-3) \text { septa } \\
\text { - Septa and wall may enhance } \\
\text { - Septa and wall may have calcification of any type } \\
\text { - Homogeneous, any size masses: } \\
\text { CT: } \\
\text { - Hyperattenuating ( } \geq 70 \mathrm{HU} \text { ) at noncontrast CT } \\
\text { - Nonenhancing > } 20 \mathrm{HU} \text { at renal mass protocol CT } \\
\text {--9 to } 20 \mathrm{HU} \text { at noncontrast CT } \\
-21 \text { to } 30 \mathrm{HU} \text { at portal venous phase CT } \\
\text { - Too small to characterize } \\
\text { MRI: } \\
\text { - Markedly hyperintense at T2-weighted imaging } \\
\text { (similar to CSF) at noncontrast } \\
\text { - Markedly hyperintense at T1-weighted imaging } \\
\text { (approximately } \times 2.5 \text { normal parenchymal signal } \\
\text { intensity) at noncontrast }\end{array}$ \\
\hline IIF & - Size criterion $>3 \mathrm{~cm}$ & $\begin{array}{l}\text { - CT: } \\
\text {-Smooth minimal thickening }(3 \mathrm{~mm}) \text { of one or } \\
\text { more enhancing septa or many }(4) \text { smooth thin } \\
(\leq 2 \mathrm{~mm}) \text { enhancing septa } \\
\text { MRI: } \\
\text { - Cystic masses that are heterogeneously } \\
\text { hyperintense at unenhanced fat-saturated } \\
\text { T1-weighted imaging } \\
\text { - Without size criterion }\end{array}$ \\
\hline III & $\begin{array}{l}\text { - Thickened or irregular walls or septa with } \\
\text { measurable enhancement }\end{array}$ & $\begin{array}{l}\text { - One or more enhancing thick ( } \geq 4 \mathrm{~mm} \text { width) or } \\
\text { enhancing irregular (displaying } \leq 3 \mathrm{~mm} \text { obtusely } \\
\text { margined convex protrusion(s)) walls or septa }\end{array}$ \\
\hline IV & $\begin{array}{l}\text { - Soft-tissue components (i.e., nodule(s)) with } \\
\text { measurable enhancement }\end{array}$ & $\begin{array}{l}\text { - One or more enhancing nodule }(\mathrm{s}) \text { ( } \geq 4 \mathrm{~mm} \text { convex } \\
\text { protrusion with obtuse margins, or a convex } \\
\text { protrusion of any size that has acute margins) }\end{array}$ \\
\hline
\end{tabular}

readers. However, the conclusion from several already published studies is not straightforward, the results of the majority of them indicate that the Bosniak Classification 2019 compared to the classification from 2005 is more accurate and objective due to incorporation of detailed measurement values of septa and walls of renal cysts. Moreover, it enables similar evaluation of cystic renal masses in MRI. One of important limitations of the new version may be categorization of a higher number of malignant masses in class IIF. Prior to widespread implementation of version 2019 in clinical practice, more studies evaluating its diagnostic performance and reader agreement are needed.

\section{Conflict of interest}

The authors declare no conflict of interest.

\section{References}

1. Bosniak MA. The current radiological approach to renal cysts. Radiology 1986; 158: 1-10.

2. Israel GM, Bosniak MA. An update of the Bosniak renal cyst classification system. Urology 2005; 66: 484-488.

3. Bosniak MA. The Bosniak renal cyst classification: 25 years later. Radiology 2012; 262: 781-785.

4. Silverman SG, Pedrosa I, Ellis JH. Bosniak classicication of cystic renal masses version 2019: an update proposal and needs assessment. Radiology 2019; 292: 475-488. 
5. Graumann O, Osther SS, Karstoff J, Horlyck A, Osther PJ. Bosniak classification system: inter-observer and intra-observer agreement among experienced uroradiologists. Acta Radiol 2015; 56: 374-383.

6. Weibi P, Klatte T, Waldert M, Remzi M. Complex renal cystic massess: current standards and controversies. Int Urol Nephrol 2012; 44: 13-18.

7. Benjaminiy O, Atr M, O’Malley M, Lobo K, Tomlinson G. Enhancing component on $\mathrm{Ct}$ to predict malignancy in cystic renal masses and interobserver agreement of different CT features. AJR 2006; 186: 665-672.

8. Smith AD, RemerEM, Cox KL, LeberML, Allen BC, ShahSN, Herts BR. Bosniak category IIF and III cystic renal lesions: outcomes and associations. Radiology 2012; 262: 152-160.

9. Smith AD, Carson JD, Sirous R, Sanyal R, Remer EM, Allen BC, Cox KL, Shuch B, Elkassem AA, Zhang X. Active surveillance versus nephronsparing surgery for a Bosniak IIF or III renal cyst: a cost-effectiveness analysis. Am J Roentgenol 2019; 212: 830-838.

10. Schoots IG, Zaccai K, Hunink MG, Verhagen PCMS. Bosniak classification for complex renal cysts reevaluated: a systematic review. J Urol 2017; 198: 12-21.

11. Davarpanah AH, Spektor M, Mathur M, Israel GM. Homogeneous T1 hyperintense renal lesions with smooth borders: is contrast-enhanced MR imaging needed? Radiology 2016; 280: 128-136.

12. Bai $X$, Sun $S M, X u$ W, Kang HH, Li L, Jin YQ, Gong QGL, Liang GC, Liu HY, Liu LL, Chen SL, Wang QR, Wu P, Guo AT, Huang QB, Zhang XJ, Ye HY, Wang HY. MRI-based Bosniak Classification of Cystic Renal Masses Version 2019: Interobserver Agreement, Impact of Readers' Experience, and Diagnostic Performance. Radiology 2020; 297: 597-605.

13. Chan J, Yan JH, Munir J. Comparison of Bosniak Classification of cystic renal masses version 2019 assessed by CT and MRI. Abdominal Radiol 2021; 46: 5268-5276.

14. Tse J, Shen J, Shen L, Yoon L, Kamaya A. Bosniak Classification of cystic renal masses version 2019: comparison of categorization using CT and MRI. Am I Roentgenol 2021; 216: 412-420.

15. Yan JH, Chan J, Osman H, Munir J, Alrasheed S, Flood TA, Schieda N. Bosniak Classification version 2019: validation and comparison to original classification in pathologically confirmed cystic masses. Eur Radiol 2021; 31:95799587.

16. Tse J, Shen J, Yoon L, Kamaya A. Bosniak Classification Version 2019 of cystic renal masses assessed with MRI Am J Roentgenol 2020; 215: 413-419.

17. Park MY, Park KJ, Kim MH, Kim JK. Bosniak Classification of Cystic Renal Masses Bosniak Classification of Cystic Renal Masses Version 2019: Comparison to Version 2005 for Class Distribution, Diagnostic Performance, and Interreader Agreement Using CT and MRI. AJR Am J Roentgenol 2021; 217: 1367-1376.

18. Pacheco EO, Torres US, Araujo Alves AM. Bosniak classification of cystic renal masses version 2019 does not increase the interobserver agreement or the proportion of masses categorized into lower Bosniak classes for non-subspecialized readers on CT or MR. Eur J Radiol 2020 131: 109270.

\section{Address for correspondence:}

\section{Dr. Katarzyna Zielińska}

Department of Radiology

Holy Cross Cancer Centre

Collegium Medicum

Jan Kochanowski University

Kielce, Poland

E-mail: badaniausgzielinska@gmail.com 